Columbia Law School

Scholarship Archive

\title{
Financial Contracts and the New Bankruptcy Code: Insulating Markets from Bankrupt Debtors and Bankruptcy Judges
}

\author{
Edward R. Morrison \\ Columbia Law School, emorri@law.columbia.edu \\ Joerg Riegel \\ Davis, Polk \& Wardwell
}

Follow this and additional works at: https://scholarship.law.columbia.edu/faculty_scholarship

Part of the Banking and Finance Law Commons, Bankruptcy Law Commons, and the Contracts Commons

\section{Recommended Citation}

Edward R. Morrison \& Joerg Riegel, Financial Contracts and the New Bankruptcy Code: Insulating Markets from Bankrupt Debtors and Bankruptcy Judges, AMERICAN BANKRUPTCY INSTITUTE LAW REVIEW, VoL. 13, P. 641, 2005, Columbia LaW School, The Center for LaW \& ECONomic StUdies Working PaPer No. 291 (2006). Available at: https://scholarship.law.columbia.edu/faculty_scholarship/2423

This Working Paper is brought to you for free and open access by the Faculty Publications at Scholarship Archive. It has been accepted for inclusion in Faculty Scholarship by an authorized administrator of Scholarship Archive. For more information, please contact scholarshiparchive@law.columbia.edu. 


\author{
Columbia Law School \\ The Center for Law and Economic Studies \\ 435 West $116^{\text {th }}$ St. \\ New York, NY 10027-7201 \\ Working Paper No. 291
}

Financial Contracts and the New Bankruptcy Code: Insulating Markets from Bankrupt Debtors and Bankruptcy Judges

Edward R. Morrison and Joerg Riegel

January 25, 2006

This paper can be downloaded without charge from the Social Science Research Network electronic library at: http://ssrn.com/abstract $=878328$

An index to the working papers in the Columbia Law School Working Paper Series is located at:

http://www.law.columbia.edu/center program/law economics 


\title{
Financial Contracts and the New Bankruptcy Code: Insulating Markets from Bankrupt Debtors and Bankruptcy Judges
}

\author{
Edward R. Morrison ${ }^{+}$and Joerg Riegel ${ }^{\ddagger}$
}

\begin{abstract}
The reforms of 2005 yield important but subtle changes in the Bankruptcy Code's treatment of financial contracts. They might appear only to eliminate longstanding uncertainty surrounding the protections available to financial contract counterparties, especially counterparties to repurchase transactions and other derivative contracts. But the ambit of the reforms is much broader. The expanded definitions-especially the definition of "swap agreement" - are now so broad that nearly every derivative contract is subject to the Code's protection. Instead of protecting particular counterparties to particular transactions, the Code now protects any counterparty to any derivative contract. Entire markets have been insulated from the costs of a bankruptcy filing by a financial contract counterparty. Equally important, the amendments limit judicial discretion to assess the economic substance of financial transactions, even those that resemble ordinary loans or that retire a debtor's outstanding debt or equity. The reforms of 2005 direct judges to apply a formalistic inquiry based on industry custom: a financial transaction is a "swap," "repurchase transaction," or other protected transaction if it is treated as such in the relevant financial market. The transaction's loan-like features or its effect on outstanding obligations of the debtor are irrelevant, unless they affect the transaction's characterization in financial markets. Absent fraud, form trumps substance-a desirable outcome, we argue, in light of the impossibility of drawing coherent lines between combinations of ordinary financial contracts and loans, dividends, or debt repurchases.
\end{abstract}

\footnotetext{
+ Associate Professor of Law, Columbia Law School.

‡ Attorney (admitted in Germany), L.L.M. Columbia Law School 2005. We thank Douglas Baird, Christian Johnson, and Hal Novikoff for helpful comments.
} 


\section{Introduction}

Financial contracts have long received special treatment under the Bankruptcy Code. Core provisions - the automatic stay, ${ }^{1}$ limitations on preferential $^{2}$ and fraudulent transfers, ${ }^{3}$ and nullification of ipso facto clauses ${ }^{4}-$ have limited application to most parties to swaps, forwards, securities contracts, and other types of financial products. When a debtor becomes insolvent or enters bankruptcy, counterparties are free to terminate agreements, liquidate positions, and set off claims against margin or other collateral posted by the debtor. ${ }^{5}$ Parties to some contracts (such as forwards) enjoyed these rights as early as the original 1978 Code. ${ }^{6}$ Parties to other contracts had to wait for amendments in the early 1980s, in 1990,7 or, most recently, in Title IX of the Bankruptcy Abuse Prevention and Consumer Protection Act of 2005 ("Act" or "Reform Act"). ${ }^{8}$

These exceptions or "safe harbors" are necessary, it is thought, ${ }^{9}$ for the protection of financial markets, including over-the-counter ("OTC") markets on which most derivative contracts are executed. Without these safe harbors, markets might suffer serious shocks - perhaps even a systemic liquidity crisis, causing markets to collapse-when debtors enter bankruptcy. Counterparties to financial contracts would find themselves subject to the automatic stay for extended periods. They would be unable to liquidate volatile contracts and thereby limit their exposure to market movements. ${ }^{10}$ Additionally, a debtor in bankruptcy would be free to "cherrypick" multiple contracts with the same

\footnotetext{
${ }^{1}$ Bankruptcy Abuse Prevention and Consumer Protection Act of 2005 ("BAPCPA"), Pub. L. No. $109-8$, §§ 1, et seq., 119 Stat. 23, et seq. (to be codified at 11 U.S.C. $§ 362(a)) ; 11$ U.S.C. $\S 362$ (a) (2000).

2 BAPCPA, Pub. L. No. 109-8, §§ 1, et seq., 119 Stat. 23, et seq. (to be codified at 11 U.S.C. § 547(b)); 11 U.S.C. § 547(b) (2000).

${ }^{3}$ BAPCPA, Pub. L. No. 109-8, $\S \S 1$, et seq., 119 Stat. 23, et seq (to be codified in 11 U.S.C $\S \S 544(b)$, 548); 11 U.S.C $\$ \S 544(b), 548$ (2000).

${ }^{4}$ BAPCPA, Pub. L. No. 109-8, §§ 1, et seq., 119 Stat. 23, et seq. (to be codified in 11 U.S.C. § 365(e)); 11 U.S.C. $\S 365(e)(2000)$.

${ }^{5}$ See infra Part I.A.

${ }^{6}$ See infra notes $22-25$ and accompanying text.

7 Id.

${ }^{8}$ BAPCPA, Pub. L. No. 109-8, $\S \S 401-47,119$ Stat. $146-85$ (to be codified as amended in scattered sections of Title 11 of the United States Code).

9 See Frank R. Edwards \& Edward R. Morrison, Derivatives and the Bankruptcy Code: Why the Special Treatment?, 22 YALE J. REG. 92, 94 (2005) (noting Congressional and academic reliance on argument).

${ }^{10}$ William J. Bergman et al., Netting, Financial Contracts, and Banks: The Economic Implications 31-32 (Fed. Res. Bank of Chicago, Working Paper No. 2004-02, 2003), available at http://papers.ssrn.com (search author "Bergmann").
} 
party. ${ }^{11}$ Instead of netting the contracts-i.e., setting-off losses under some contracts against gains under others with the same counterparty - the debtor could dispose of the contracts independently. "In-the-money" contracts could be assumed; "out-of-the-money" contracts could be rejected. In this way, the debtor could lock-in gains on profitable contracts and (due to its insolvency) limit liability for losses under unprofitable ones. The counterparty to these contracts would find itself paying in full on the assumed contracts and receiving only a fraction of its claim on the rejected. Losses from indefinite exposure to market movements and from cherrypicking could produce financial distress in the counterparty itself, ${ }^{12}$ forcing it to default on its own contracts with other parties. As one distressed party infects another, a domino effect could ensue, undermining the entire financial market. ${ }^{13}$

This theory was cited repeatedly ${ }^{14}$ as Congress acted in 2005 to expand the range of protections available to financial contract counterparties. ${ }^{15}$ Prior to the Reform Act, nontrivial uncertainty surrounded the range of transactions and contractual rights covered by the Code's exceptions and the types of parties eligible to take advantage of those exceptions. As we show in Part I, the Act goes a long way toward eliminating this uncertainty by dramatically expanding the range of financial contracts (especially repos, swaps, and margin loans), counterparties, and contractual rights (especially cross-product netting) that receive protection under the Code. ${ }^{16}$ The expansion is particularly striking for derivative contracts, such as forwards, futures, swaps, and options. Prior to 2005, the Code's protections were broad for swaps (any counterparty received protection) and narrow for other derivative contracts (only some counterparties were protected). ${ }^{17}$ The Act obliterates this asymmetry, principally by redefining

\footnotetext{
${ }^{11}$ See Edwards \& Morrison, supra note 9, at 95-96 (explaining the "cherrypicking" power in greater detail). 
"swap" to include, effectively, all derivative contracts. ${ }^{18}$ In so doing, the Code has moved from protecting particular parties to protecting entire markets.

The new Code achieves this market protection through broad-ranging definitions of protected transactions and contractual rights. With broad definitions come line-drawing problems, of course. The definitions, for example, now encompass many transactions that, singly or in combination, have distinct loan-like elements. ${ }^{19}$ Examples include repos, total return swaps combined with stock purchases, and combinations of prepaid and postpaid forwards. When does a transaction's credit component become sufficiently important that the transaction falls outside the range of protected financial transactions?

Another puzzle arises from the Code's protections for "settlement payments" by or to protected parties, including payments made a few days before the debtor's bankruptcy filing. ${ }^{20}$ Does this protection encompass payments to the debtor's own equityholders and bondholders? Examples include leveraged buyout payments ("LBO") to shareholders and settlement payments to bondholders under debt repurchases. Should bankruptcy judges prevent the Code's financial contracts provisions from sheltering what would otherwise amount to constructively fraudulent or preferential transfers?

We address these questions in Part II and show that the answers are left, in large part, to the marketplace. The Code's definitions are based exclusively on market definitions. A transaction is protected if, in the judgment of market participants, it falls within a category of transactions included in the Code and recognized in the marketplace. A payment is protected if a market participant would call it a settlement payment. Instead of asking judges to assess the economics of a transaction and distinguish "true" financial contracts from "shams," the Code asks judges to rely on industry custom.

Indeed, if anything is clear from the new Code, it is that judges are strongly discouraged from engaging in functional analysis of financial contracts. The Code's protections encompass contracts or combinations of contracts that differ little in substance from unprotected transactions, such as secured loans. They are protected because they are recognized in financial markets as financial contracts. Any judicial effort to distinguish protected and unprotected contracts based on their "substance" is doomed to failure and can only generate significant

18 See infra notes $62-75$ and accompanying text.

19 See infra Part II.A.

${ }^{20}$ See infra Part II.B. 
uncertainty in the very markets the Code seeks to protect. By relying on broad market definitions, the Act gets judges out of the (largely futile) business of second-guessing financial contracts. Absent evidence of intent to defraud a debtor's creditors, which remains ground for denying protection to payments under a financial contract, the new role of judges is to apply industry custom to financial contracts in much the same way that they would apply custom to interpret a contract under the Uniform Commercial Code. ${ }^{21}$

\section{The Code's New Bright Lines}

The Reform Act might seem to perform a modest function, tying up loose ends created by multiple, somewhat inconsistent amendments to the Code over the past 25 years. Starting with commodity and forward contracts, which received protection under the original 1978 Code, ${ }^{22}$ Congress added protection for securities contracts in $1982,{ }^{23}$ repurchase agreements in $1984,{ }^{24}$ and swaps in $1990 .{ }^{25}$ For each transaction, Congress specified - separately and in terms that have varied over time-protections available to counterparties. This patchwork approach to the Code generated some confusion, particularly about the scope of protected transactions and the range of protections available to counterparties. Moreover, although the various amendments addressed similar (and sometimes identical) transactions, the amendments did not refer to each other, raising difficult statutory interpretation questions.

Title IX of the Reform Act remedies most of these problems and, in doing so, might seem to perform a modest housekeeping function. But Title IX is hardly modest, for it marks a large shift in the structure of exemptions for derivative contracts: instead of protecting particular parties, the Code now protects entire markets.

\footnotetext{
${ }^{21}$ See U.C.C. $\S \S 1-102,1-103$ (2005). See generally Lisa Bernstein, Private Commercial Law in the Cotton Industry: Creating Cooperating Through Rules, Norms, and Institutions, 99 MiCH. L. Rev. 1724, 1735 (2001) ("Broadly speaking, the Code directs courts to look to immanent business norms reflected in course of dealing, course of performance, and usage of trade, to fill gaps and interpret contracts ....").

${ }^{22}$ See, e.g., Bankruptcy Reform Act of 1978, Pub. L. No. 95-598, §§ 362(b)(6), 548(d)(2)(B), 1978 U.S.C.C.A.N. (92 Stat.) 2549.

${ }^{23}$ Act of July 27, 1982, Pub. L. No. 97-222, §§ 1, et seq., 96 Stat. 235 (codified as amended at various provisions of Title 11 of the United States Code).

${ }^{24}$ Bankruptcy Amendments and Federal Judgeship Act of 1984, Pub. L. No. 98-353, §§ 391, et seq., 98 Stat. 333, (codified as amended at various provisions of Title 11 of the United States Code). ${ }^{25}$ Act of June 25, 1990, Pub. L. No. 101-311, §§ 101, et seq., 104 Stat. 267 (codified as amended at various provisions of Title 11 of the United States Code).
} 


\section{A. The Original Structure: Incomplete Market Protection}

The broad outlines of the Code remain unchanged after the Reform Act. Parties to five basic categories of financial contracts-repurchase agreements, commodity contracts, forward contracts, swap agreements, and securities contracts - enjoy a limited exception from the Code's automatic stay, its prohibition on ipso facto clauses in executory contracts, and its preference and fraudulent conveyance rules.

Many contracts (financial and nonfinancial) enable a counterparty to terminate or modify the contract if the debtor suffers distress or enters bankruptcy (an example is a clause accelerating the debtor's obligations in the event of insolvency). The contract may also allow the counterparty to seize collateral and exercise setoff rights. These setoff rights allow the counterparty to subtract its liabilities to the debtor from its claims against the debtor, thereby reducing its claims against the debtor (and its exposure to nonpayment).

Generally, these contractual rights are limited when a debtor enters bankruptcy. Section 365(e) nullifies contractual provisions, including acceleration and termination clauses, which alter the debtor's rights in the event of financial distress. ${ }^{26}$ Similarly, the automatic stay of section 362 restricts attempts to seize collateral or exercise setoff rights. ${ }^{27}$ Moreover, a debtor's eve-of-bankruptcy payments to a counterparty may run afoul of the Code's preference ${ }^{28}$ and fraudulent conveyance rules. ${ }^{29}$

These limits on counterparty rights, however, do not apply when the underlying contract is a financial contract and the counterparty is a "protected party." Protected parties enjoy the same rights in bankruptcy as they do outside. They are free to close-out the agreement, exercise certain setoff rights, and foreclose on margin-before or after the debtor enters bankruptcy. The Code calls off the automatic stay, ${ }^{30}$ prohibition on ipso facto clauses, ${ }^{31}$ and its

\footnotetext{
2611 U.S.C. §365(e) (2000).

${ }^{27}$ BAPCPA, Pub. L. No. 109-8, §§ 1, et seq., 119 Stat. 23, et seq. (to be codified at 11 U.S.C. $\S$ 362(a)); 11 U.S.C. $\S 362(a)(2000)$.

${ }^{28}$ BAPCPA, Pub. L. No. 109-8, §§ 1, et seq., 119 Stat. 23, et seq. (to be codified at 11 U.S.C. § 547); 11 U.S.C. § 547(b) (2000).

${ }^{29}$ BAPCPA, Pub. L. No. 109-8, §§ 1, et seq., 119 Stat. 23, et seq. (to be codified at 11 U.S.C. § 544(b), 548); 11 U.S.C. $\S \S 544(b), 548$ (2000).

${ }^{30}$ BAPCPA $\S \S 907(\mathrm{~d})(1)(\mathrm{A}),(\mathrm{o})(1)$ (to be codified at 11 U.S.C. $\left.\S 362(\mathrm{~b})(6)\right)$ (permitting setoff, notwithstanding automatic stay, by certain counterparties to commodity, forward, and securities contracts); id. at $\S \S 907(\mathrm{~d})(1)(\mathrm{B})$, (o)(2) (to be codified at 11 U.S.C. $\S 362(\mathrm{~b})(7)$ ) (creating similar safe
} 
preference and constructive fraudulent conveyance rules. ${ }^{32}$ These protections are available to any counterparty to a swap or repurchase agreement. Counterparties to other protected financial contracts-forward, commodity, and securities contracts - received more limited protections prior to the Reform Act. Under the old Code, exemptions from the automatic stay and the limitation on ipso-facto clauses were available only to brokers, forward contract merchants, banks, and certain other protected entities. ${ }^{33}$ Along the same lines, exemptions from the preference and fraudulent transfer rules were available to any counterparty, provided the transfer was made by or to one of those protected entities. ${ }^{34}$

This statutory scheme sounds fairly simple, but the simplicity depends critically on the clarity of its definitions. And the definitions - of protected transactions, parties, and contractual rights - have not been easy to apply, particularly with respect to the innovative financial transactions developed during the past 15 years.

The definitions of protected transactions have been particularly troubling. The definition of "swap agreement," for example, became part of the Code in 1990 and set out a non-exhaustive list of swap-like transactions - rate, basis,

harbor for repo participants); id. at § 907(d)(1)(C) (to be codified at 11 U.S.C. § 362(b)(17)) (creating similar safe harbor for swap participants).

${ }^{31}$ BAPCPA $\S \S 907(\mathrm{~g}),(\mathrm{o})(7),(\mathrm{p})(1)(\mathrm{A})$ (to be codified at 11 U.S.C. $\left.\S 555\right)$ (exempting ipso facto clauses in securities contracts); id. at $\$ \S 907(\mathrm{~h}),(\mathrm{o})(8),(\mathrm{p})(1)(\mathrm{A})$ (to be codified at 11 U.S.C. $\S 556$ ) (exempting ipso facto clauses in commodity and forward contracts); id. at $\S \S 907(\mathrm{i}),(\mathrm{o})(9)$, (p)(1)(B) (to be codified at 11 U.S.C. § 559) (exempting ipso facto clauses in repurchase agreements); id. at $\S \S 907(\mathrm{j}),(\mathrm{o})(10),(\mathrm{p})(1)(B)$ (to be codified at 11 U.S.C. $\S 560)$ (exempting ipso facto clauses in swaps).

32 BAPCPA § 907(o)(3) (to be codified at 11 U.S.C. § 546(e)) (declaring that, unless payment was fraudulent transfer under $\S 548(\mathrm{a})(1)(\mathrm{A})$, trustee cannot use its powers under $\S \S 544,545,547$, $548(\mathrm{a})(1)(\mathrm{B})$, and 548(b) to avoid margin or settlement payments by or to protected parties to commodity, forward, and securities contracts prior to case commencement); id. at $\S 907$ (o)(2) (to be codified at 11 U.S.C. §546(f)) (offering same safe harbor for margin or settlement payments in connection with repurchase agreements); $i d$. at $\S \S 406(1), 907(\mathrm{e})(1)$ (to be codified at 11 U.S.C. $\S$ $546(\mathrm{~g}))$ (offering same safe harbor for transfers under or in connection with swap agreements). ${ }^{3}$ See 11 U.S.C. § 362(b)(6) (2000) (making exemption from automatic stay available to "a commodity broker, forward contract merchant, stockbroker," and other specified parties to forward, commodity, and securities contracts); id. at $\S 555$ (making exemption from prohibition on ipso facto clauses available to particular parties to securities contracts), $i d$. at $\S 556$ (making same exemption available to particular parties to commodity and forward contracts).

${ }^{34} 11$ U.S.C. § 546(e) (2000); see also In re Kaiser Steel Corp., 952 F.2d 1230, 1241 (10th Cir. 1991) (protecting payments under securities contract to shareholder, even though shareholder was not protected party under section 546(e), because payments were made by stockbroker, clearing agency, or financial institution). 
commodity, currency, and cross-currency rate swaps; interest rate and currency options; rate caps, floors, and collars; and "any other similar agreement." ${ }^{35}$ None of these transactions was defined by the Code; a judge was presumably expected to rely on standard market definitions. ${ }^{36}$ Although flexible and seemingly exhaustive in scope, ${ }^{37}$ the "swap agreement" definition proved worrisome because it had to be stretched to cover equity swaps, credit default swaps, total return swaps, weather derivatives, and other transactions that became increasingly popular in the 1990s.

The definitions of protected contractual rights have been equally problematic. The problem stemmed largely from the structure of the Code, which described the protected rights separately for each type of financial contract. Section 362(b)(6) protected contractual setoff rights with respect to commodity, forward, and securities contracts, section 362(b)(7) did the same for repurchase agreements, and 362(b)(17) did it for swaps. ${ }^{38}$ By explicitly protecting setoff rights within groups of financial products, was the Code implicitly limiting the exercise of contractual setoff rights across groups of products? ${ }^{39} \mathrm{~A}$ limit on cross-product netting across groups of financial contracts would make counterparties vulnerable to the financial distress of debtors, a result which

${ }^{35} 11$ U.S.C. § 101(53B) (2000).

${ }^{36}$ And this is what judges have done:

By way of guidance in ascertaining the meaning of "settlement payment," as the term relates to both $\S 546(\mathrm{e})$ and companion provisions in $\S 546(\mathrm{f})$, Congress made clear that the provisions are to be defined with reference to the common understanding, practice and usage in the securities industry. . . Further reflecting actual industry practice and definitional understanding, the Bankruptcy Code expressly extends its reach to cover several particular kinds of financial transactions which rely upon the concept of settlement payments.

Jackson v. Mishkin (In re Adler, Coleman Clearing Corp.), 263 B.R. 406, 475 (S.D.N.Y. 2001); see also Thrifty Oil Co. v. Bank of Am. Nat'1 Trust and Savs. Ass'n, 322 F.3d 1039, 1042-43 (9th Cir. 2002) (relying on expert opinion to define interest rate swaps); In re Interbulk, 240 B.R. 195, 200 01 (Bankr. S.D.N.Y. 1999) (utilizing market definitions of "swap agreement").

${ }^{37}$ Allen \& Overy Memorandum on U.S. Netting Legislation for ISDA, at 2 (April 2, 2001), available at www.isda.org/speeches/pdf/Memorandum_for_ISDA-US-Netting-Legislation.pdf (explaining how market definition encompassed "known universe of privately negotiated derivatives at the time").

38 See supra note 30 and accompanying text.

${ }^{39}$ See Allen \& Overy Memorandum on U.S. Netting Legislation, supra note 37, at 2 (noting uncertainty surrounding this question). 
seems inconsistent with the Code's goal of reducing systemic risk in financial markets. ${ }^{40}$

Finally, the definitions of protected parties led to an asymmetry between swaps and repurchase agreements, on one hand, and forward, commodity, and securities contracts, on the other. Any swap or repurchase agreement counterparty ${ }^{41}$ enjoyed the Code's protections, but only some counterparties to the other contracts could say the same. ${ }^{42}$ As a result, a pension fund or oil company might find itself protected with respect to swaps but unprotected with respect to forwards with the very same party. ${ }^{43}$

\section{B. The New Code: Protecting Markets}

The Reform Act radically reworks the Code's definitions, expanding them to cover a broad range of transactions that are or become common in financial markets. One of the more important changes (more on this below) is contained in the definition of "swap agreement." 44 In its new form, essentially all derivatives have become "swap agreements;" all parties to them, and all transfers under or in connection with them, enjoy the Code's protections. ${ }^{45}$ For derivatives, at least,

\footnotetext{
${ }^{40}$ Prior to the Reform Act, practitioners were also unsure whether the Code protected a counterparty's rights under arrangements adjunct to the transaction itself, such as a security agreement. Arguably it did. Section 362(b) created a safe harbor for the exercise of setoff rights "under or in connection with" a financial contract. 11 U.S.C. $\S \S 362(b)(6),(7),(17)$ (2000) (emphasis added).

${ }^{41}$ See, e.g., 11 U.S.C. § 101(53C) (2000) (defining "swap participant" as "entity that, at any time before the filing of the petition, has an outstanding swap agreement with the debtor"); id. at $\S$ 362(b)(17) (offering "swap participants" exemption from automatic stay).

42 See, e.g., 11 U.S.C. § 362(b)(6) (2000) (offering exemption from automatic stay only to commodity brokers, forward contract merchants, stockbrokers, financial institutions, and certain other counterparties to commodity, forward, and securities contracts).

${ }^{43}$ A similar argument was pressed by the International Swaps and Derivatives Association, Inc. (ISDA) and the Public Securities Association ("PSA," now known as the Bond Market Association) in a joint position paper, which proposed legislation that, for the most part, became the text of the Reform Act. See ISDA AND PSA ON FINANCIAL TRANSACTIONS IN INSOLVENCY: REDUCing LegAL RisK THROUGH LegisLATIVE REFORM (1996), at 8, http://www.isda.org/ speeches/pdf/FinancialTransinInsolvency.pdf.

${ }^{44}$ See H.R. Rep No. 109-31, supra note 14, at 128 (describing amendment as an "update [of] the statutory definition [that will] achieve contractual netting across economically similar transactions").

${ }^{45}$ The breadth of the new swap agreement definition is acknowledged in the Act's legislative history. Id. at 129 ("The use of the term 'forward' in the definition of 'swap agreement' is not intended to refer only to transactions that fall within the definition of 'forward contract.' Instead, a 'forward' transaction could be a 'swap agreement' even if not a 'forward contract.'”).
} 
the Act now offers financial market protection, a significant departure from the old paradigm of protection for particular parties.

In principle, the Act retains the five basic categories of protected transactions - securities contracts, swaps, repurchase agreements, forwards, and commodity contracts. The definition of each transaction is restructured and updated. Every definition now begins with a description of the product itself and then lists various related transactions, such as contracts that combine several versions of the product, options to enter into the product, and master agreements or security agreements involving the product. ${ }^{46}$ The description of the product itself defers to industry definitions, as before, but now includes an expanded list of products that are actively traded in organized or OTC markets. The number of listed transactions has increased significantly for swap agreements, securities contracts, and repurchase agreements. ${ }^{47}$ Forward and commodity contracts are given less dramatic face-lifts. Equally important, most definitions now include an "opening clause," which extends the Code's protection to any transaction that is "similar" to one listed in the definition itself. ${ }^{48}$

${ }^{46}$ See BAPCPA § 907(a)(1)(A) (to be codified at 11 U.S.C. § 101(25)) (defining forward contract); $i d$. at $\S 907(\mathrm{a})(1)(\mathrm{C})$ (to be codified at 11 U.S.C. $\S 101(47)$ ) (defining repurchase agreement); id. at $\S$ 907(a)(1)(E) (to be codified at 11 U.S.C. § 101(53B)) (defining swap agreement); id. at § 907(a)(2) (to be codified at 11 U.S.C. $\S 741(7)$ ) (defining securities contract); id. at $\S 907$ (a)(3) (to be codified at 11 U.S.C. § 761(4)) (defining commodity contract); see also H.R. ReP No. 109-31, supra note 14, at 129 (explaining that protected transactions include "any security agreement or arrangement, or other credit enhancement, related to a" protected transaction).

${ }^{47}$ One particularly noteworthy addition includes "margin loans" as one of the categories of "securities contracts." Also expressly included are "repurchase or reverse repurchase transactions." Compare 11 U.S.C. § 741(7) (2000), with BAPCPA § 907(a) (to be codified at 11 U.S.C. $\S 741(7)(\mathrm{A})(\mathrm{i})$, (iv)).

${ }^{48}$ Opening clauses are added to the definitions of securities contracts, commodity contracts, and forward contracts. See BAPCPA § 907(a)(2) (to be codified at 11 U.S.C. § 741(7)(A)(v)) (amending definition of securities contract to include "any other agreement or transaction that is similar to an agreement or transaction referred to in this subparagraph"); id. at $\S 907(a)(3)$ (B) (to be codified at 11 U.S.C. $\S 761(4)(\mathrm{F}))$ (amending definition of commodity contracts in same manner); $i d$. at $\S$ 907(a)(1)(A) (to be codified at 11 U.S.C. § 101(25)(A)) (amending definition of "forward contract" to include "any other similar agreement"). The preexisting opening clause for swaps, 11 U.S.C. 101(53B)(A) (2000) (encompassing "any other similar agreement"), was modified to include "any agreement or transaction that is similar to any other agreement or transaction referred to in this paragraph and that" has been, is now, or becomes the "subject of recurrent dealings in the swap markets" and is a "forward, swap, future," or other listed transaction. BAPCPA § 907(a)(1)(E) (to be codified at 11 U.S.C. § 101(53B)(A)(ii)). The legislative history explains that "the definition of 'swap agreement' was originally intended to provide sufficient flexibility to avoid the need to amend the definition as the nature and uses of swap transactions matured. To that end, the phrase 'or any other similar agreement' was included in the definition. (The phrase 'or any 
The definition of "securities contract" is instructive. Prior to 2005, it covered any "contract for the purchase, sale, or loan of a security, certificate of deposit, or group or index of securities." ${ }^{49}$ In the new Code, that definition is replaced with a laundry list: a "securities contract" is "a contract for the purchase, sale, or loan of a security, a certificate of deposit, a mortgage loan or any interest in a mortgage loan, a group or index of securities, certificates of deposit, or mortgage loans or interests therein, ... any option on any of the foregoing,.. any repurchase or reverse repurchase transaction ...., any margin loan," and several other transactions..$^{50}$ Among the elements of this list, the express protection of "repurchase and reverse repurchase transactions" is of particular importance, as we explain in Part II.A below. Significantly, a "securities contract" also includes "any other agreement or transaction that is similar to an agreement or transaction referred to in this subparagraph." ${ }^{11}$ Little is left to the imagination; we need only look to the marketplace now or in the future to determine what constitutes a "securities contract."

In addition to enlarging the five basic categories of financial transactions, the Act creates a new super-category, the "master netting agreement," which is a contract that sets out rights of termination, acceleration, and setoff within and across multiple financial transactions within a single contract. ${ }^{52}$ The primary effect of adding this new category is to expand the range of protected contractual rights. Under new sections 362(b)(27), 546(j), 548(d)(2)(E), and 561, ${ }^{53}$ these rightsincluding cross-product netting ${ }^{54}$-are now protected across all financial contracts, if exercised under a master netting agreement. ${ }^{55}$ Recall that crossproduct netting enjoyed an uneasy legal status prior to 2005. ${ }^{56}$

similar agreement' has been added to the definitions of 'forward contract,' 'commodity contract,' 'repurchase agreement' [sic] and 'securities contract' for the same reason.)" H.R. REP. No. 109-31, supra note 14, at 128 . Although the foregoing statement suggests otherwise, an opening clause has not yet been added to the definition of "repurchase agreement." See BAPCPA, § 907(a)(1)(C) (to be codified at 11 U.S.C. § 101(47)); 11 U.S.C. § 101(47) (2000).

${ }^{49} 11$ U.S.C. § 741(7) (2000).

${ }^{50}$ BAPCPA § 907(a)(2) (to be codified at 11 U.S.C. § 741(7)(A)).

${ }^{51}$ See supra note 48 and accompanying text.

52 BAPCPA $\S 907$ (c) (to be codified at 11 U.S.C. $\S 101(38$ A)).

${ }^{53}$ BAPCPA $\S 907($ d)(1)(D) (to be codified at 11 U.S.C. $\S 362(\mathrm{~b})(27)$ ); id. at $\S 907(\mathrm{e})(2)$ (to be codified at 11 U.S.C. $\S 546(\mathrm{j})$ ); id. at $\S 907(\mathrm{f})(3)$ (to be codified at 11 U.S.C. $\S 548(\mathrm{~d})(2)(\mathrm{E})$ ); id. at $\S 907(\mathrm{k})$ (to be codified at 11 U.S.C. $\S 561$ ).

${ }^{54}$ Some netting and setoff rights, however, are limited in transactions involving commodity brokers. See BAPCPA § 907(k)(1) (to be codified at 11 U.S.C. § 561(b)(2)).

${ }^{55}$ Multi-party netting may also find protection under the Reform Act. The Code offers limited protection for any setoff right-regardless of whether it arises from financial contracts-provided 
In principle, the Act also retains the concept of protected parties. With respect to forward, commodity, and securities contracts, the original Code singled out particular parties for protection - a "commodity broker, forward contract merchant, stockbroker, financial institution[], or securities clearing agency." 57 The Act expands this list ${ }^{58}$ to include any counterparty that is a "financial participant," defined as a clearing organization or an entity that entered protected financial transactions (swaps, repos, forwards, etc.) worth at least $\$ 1$ billion in notional value (or $\$ 100$ million in mark-to-market value) at some point during the preceding 15 months. ${ }^{59}$ In effect, the Code now exempts "sophisticated" financial participants from the reach of the automatic stay and other provisions. ${ }^{60}$

it involves the setoff of a "mutual debt" owed to the debtor against a claim owed by the debtor. BAPCPA § 907(n) (to be codified at 11 U.S.C. § 553(a)); 11 U.S.C. § 553(a) (2000). Although not defined in the Code, "mutuality" is thought to require at least that the party indebted to the debtor is the same party holding a claim against the debtor. See generally Rhett Campbell, Energy Future and Forward Contracts, Safe Harbors and the Bankruptcy Code, 78 AM. BANKR. L.J. 1, 26-29 (2004). Put differently, "mutuality" may not be satisfied if the claim is held by a creditor but the debt is owed by a subsidiary or affiliate of the creditor. Mutuality would, of course, be satisfied if the subsidiary or affiliate transferred its debt to the creditor, provided the transfer did not occur within 90 days of the debtor's bankruptcy filing. BAPCPA $\S 907(\mathrm{n})$ (to be codified at 11 U.S.C. $\S$ 553(a)(2)). Prior to the Reform Act, it was uncertain whether this 90-day "mini-preference" rule applied to protected financial contracts. Campbell, supra, at 26-29. Some of this uncertainty is resolved by the Reform Act, which explicitly protects rights of setoff under protected financial contracts that were acquired by a protected counterparty at any time prior to the debtor's bankruptcy filings. BAPCPA § 907(n) (to be codified at 11 U.S.C. §§ 553(a)(2)(B)(ii), (3)(C)). Now affiliates can transfer claims or obligations to each other and then subtract the aggregate value of their claims against the debtor from the total amount of their obligations to the debtor, effectively exercising multi-party close-out netting.

56 See notes 38-40, supra, and accompanying text.

5711 U.S.C. $\S \S 362(b)(6), 555,556$ (2000).

${ }^{58}$ Additional, small changes are made to the definitions of "financial institution" (which now includes federally-insured credit unions) and "forward contract merchant" (now includes Federal reserve banks). See BAPCPA $\S \S 907(b)(1)$, (3) (to be codified at 11 U.S.C $\S 101(22)$, (26)).

${ }^{59}$ BAPCPA § 907(b)(2) (to be codified at 11 U.S.C. § 101(22A)).

${ }^{60}$ Interestingly, the term "financial participant" has also been added to sections 362(b)(17) and 546(g), which offer safe harbors for pre-petition transfers and in-bankruptcy setoffs by "a swap participant or financial participant." BAPCPA $\S 907(d)(1)(c),(e)(1)(c)$ (to be codified at 11 U.S.C. §§ 362(b)(17), 546(g)) (emphasis added). Why add "financial participant" when the definition of "swap participant" already encompasses any entity that "has an outstanding swap agreement with the debtor?" The legislative materials explain that the addition was thought helpful in ensuring protection for clearing organizations (a type of "financial participant" listed in BAPCPA $\S 907(\mathrm{~b})(2)$ (to be codified at 11 U.S.C § 101(22A)(B)), which may receive or deliver payments 
Based on these and other amendments, ${ }^{61}$ it would seem that the Reform Act merely builds upon the Code's existing tripartite structure for financial contracts - the scope of protected contracts is enlarged, the number of protected parties is increased, and the range of protected contractual rights is broadened. This impression, we believe, is somewhat misleading. For a large proportion of financial contracts, the tripartite structure has been dismantled.

This is the product of massive changes to the definition of "swap agreement." Old section 101(53B) defined it as a swap involving currencies, interest rates, commodities, or "any other similar agreement," including "any combination of" or "master agreement for" such agreements. ${ }^{62}$ The newly amended definition covers these transactions as well as options, forwards, and futures involving the same subject matter. ${ }^{63}$ Additionally, a "swap agreement" now includes swaps, options, forwards, and futures on debt ${ }^{64}$ or equity ${ }^{65}$ and various other derivative products, such as credit swaps, ${ }^{66}$ total return swaps, ${ }^{67}$ and weather options. ${ }^{68}$ And there is the familiar opening clause, ${ }^{69}$ making clear that nearly all "similar" agreements are covered as well. ${ }^{70}$

under a swap agreement even though it is not formally a party to the agreement. See H.R. REP. No. 109-31, supra note 14, at 131.

${ }^{61}$ Several other changes are notable. One makes clear that a swap counterparty can set off its own obligations to the debtor against any collateral securing the swap agreement, including collateral pledged by the debtor but held by the debtor itself (e.g., receivables) or by third parties (e.g., resold securities). BAPCPA § 907(d)(1)(C) (to be codified at 11 U.S.C. § 362(b)(17)); H.R. REP. NO. 109-31, supra note 14, at 132. Another amendment makes clear that the financial-contract safe harbors extend to pre-petition attachment of or foreclosure on debtor property by a swap counterparty. BAPCPA § 907(e)(1) (to be codified at 11 U.S.C. § 546(g)). Previous case law had reached the opposite conclusion. See, e.g., In re Interbulk, 240 B.R. 195, 201-03 (Bankr. S.D.N.Y. 1999). Other amendments replace terms such as "liquidation" and "termination" with the phrase "liquidation, termination, or acceleration" in various sections, thereby clarifying the range of contractual rights exempt from the prohibition on ipso facto clauses. See, e.g., BAPCPA $\S$ 907(g)(2), (h)(2), (i)(2), (j)(2) (to be codified at 11 U.S.C. $\S \S 555,556,559,560)$. Finally, the Reform Act adds a new damages calculation provision. Id. at $\S 910$ (to be codified at 11 U.S.C. $\S 562$ ).

6211 U.S.C. § 101(53B) (2000).

${ }^{63}$ BAPCPA $\S 907(a)(1)(E)$ (to be codified at 11 U.S.C $\S 101(53 B)(A)(\mathrm{i})(\mathrm{I})-(\mathrm{III})$ ).

${ }^{64} \mathrm{Id}$. at $\S 907(\mathrm{a})(1)(\mathrm{E})$ (to be codified at 11 U.S.C $\S 101(53 \mathrm{~B})(\mathrm{A})(\mathrm{i})(\mathrm{V})$ ).

${ }^{65} \mathrm{Id}$. at $\S 907(\mathrm{a})(1)(\mathrm{E})$ (to be codified at 11 U.S.C $\S 101(53 \mathrm{~B})(\mathrm{A})(\mathrm{i})(\mathrm{IV})$ ).

${ }^{66} \mathrm{Id}$. at $\S 907(\mathrm{a})(1)(\mathrm{E})$ (to be codified at 11 U.S.C $\S 101(53 \mathrm{~B})(\mathrm{A})(\mathrm{i})(\mathrm{VI})$ ).

${ }^{67} \mathrm{Id}$.

${ }^{68} I d$. at $\S 907(a)(1)(E)$ (to be codified at 11 U.S.C. $\S 101(53 B)(A)(\mathrm{i})(\mathrm{VIII})$ ).

${ }^{69}$ BAPCPA § 907(a)(1)(E) (to be codified at 11 U.S.C. § 101(53B)(A)(ii)).

${ }^{70}$ We say "nearly all" because the opening clause applies to "forward, swap, future, or option" agreements that (I) have been, are now, or become "subject of recurrent trading in the swap markets" and (II) are written on "one or more rates, currencies, commodities, equity securities, . . 
These amendments do much more than simply expand the list of protected swaps. They expand it to include virtually every contract traded in derivatives markets, including particular contracts-options, ${ }^{71}$ forwards, ${ }^{72}$ and certain futures $^{73}$-that are given more limited protection elsewhere in the Code. ${ }^{74}$ It is difficult to imagine a derivative that would not be encompassed by section 101(53B). Equally important, these amendments also extend the Code's protections to every counterparty to a derivative contract because the definition of "swap participant" remains unchanged. It continues to encompass any entity that "at any time before the filing of the petition, has an outstanding swap agreement with the debtor."75 As a result, the amendments to "swap agreement," move the Code from protecting particular parties (to forwards and commodity contracts) to protecting entire derivatives markets.

This shift in the Code effectively eliminates the concept of protected parties with respect to forwards and commodity contracts. Any counterparty to these contracts is a "swap participant" and therefore protected. ${ }^{76}$ This conclusion creates no tension with the various provisions - 362(b)(6), 546(e), and 556-that permit only certain parties to forward and commodity contracts to enjoy the Code's safe harbors. These provisions protect particular parties, but they do not

\footnotetext{
. debt securities ..., quantitative measures associated with an occurrence ..., or economic or financial indices...." Id.

${ }^{71}$ See, e.g., id. at § 907(a)(2) (to be codified at 11 U.S.C. $\S 741(7)(A)(i)$ ) (defining "securities contract" to include options on protected securities contracts); id. at $\S 907(\mathrm{a})(2)$ (to be codified at 11 U.S.C. § 741(7)(A)(ii)) (including exchange-traded options on foreign currencies); id. at § 907(a)(3) (to be codified at 11 U.S.C. $§ 761(4)($ E)) (including commodity options within definition of commodity contract).

${ }_{72}$ Id. at § 907(a)(1)(A) (to be codified at 11 U.S.C. § 101(25)) (defining forward contract as "a contract (other than a commodity contract) for the purchase, sale, or transfer of a commodity.").

${ }^{73}$ Some futures are covered by the definition of "commodity contract." Id. at § 907(a)(1)(A) (to be codified at 11 U.S.C. § 761(4)); 11 U.S.C. § 761(4) (2000); see, e.g., In re Olympic Natural Gas Co., 294 F.3d 737, 741 (5th Cir. 2002) (explaining definition of "commodity contract" includes onexchange-traded futures transactions).

${ }^{74}$ Nearly all derivatives contracts can be reduced to combinations of options, forwards, and swaps. See, e.g., Norman M. Feder, Deconstructing Over-The-Counter Derivatives, 2002 ColuM. Bus. L. REV. 677, 691 n.24.

7511 U.S.C. § 101(53C) (2000).

${ }^{76}$ Thus, producers (e.g., oil companies) and end-users that enter forward contracts should now enjoy the same protections as brokers, banks, and other "protected parties." A largely opposite conclusion was reached under the pre-2005 Code. See, e.g., Mirant Americas Energy Mktg. v. Kern Oil \& Ref. Co. (In re Mirant Corp.), 310 B.R. 548, 570 (Bankr. N.D. Tex. 2004) (finding that protection as "forward contract merchant" requires to "have entered into the Agreements as a participant seeking profit in the forward contract trade" under sections 362(b)(6) and 556, and not "for its own consumption or as a producer").
} 
rule out safe harbors for other counterparties under other provisions of the Code. Indeed, courts have long recognized significant overlap in the Code's definitions, ${ }^{77}$ and Congress was fully aware that the new definition of "swap agreement" would cover all forwards. ${ }^{78}$ Indeed, legislative history indicates that Congress was aware that all of the Code's definitions overlap considerably. ${ }^{79}$

\section{What are the Boundaries of the New Code?}

A principal goal of the Act, then, is to expand dramatically the range of protected financial contracts. Entire derivatives markets are now protected. The Act achieves this goal primarily through definitions that are simply long lists of financial products observed (now or in the future) in financial markets. The virtue of this formalistic approach is that it leaves little doubt about the Code's boundaries: any transaction that bears the formal markings of a swap, repo, forward, commodity contract, or securities contract is protected. It is largely unnecessary for judges to analyze the economics of particular transactions.

But the Act's simplicity comes with a price: as it extends the range of protected contracts, it may encompass transactions lying on the boundary between financial contracts and ordinary loans. Many financial contracts have a credit component; one party temporarily extends credit to the other. Sometimes, this component is even the dominant or exclusive feature of the transaction, as in repos and other transactions that combine multiple financial contracts (e.g., securities purchases and forwards) and, in doing so, replicate an ordinary loan. Prior to the Reform Act, judges sometimes analyzed the economics of the transaction and attempted to draw lines between true financial contracts and ordinary loans. Is there any room for such line drawing now? We address this question in Section II.A.

\footnotetext{
77 See, e.g., Hamilton Taft \& Co. v. Howard, Weil, Labouisse, Freidrichs, Inc. (In re Hamilton Taft \& Co.), 114 F.3d 991, 992 (9th Cir. 1997) (finding overlap between section 546(f) and 546(e) and holding that sections meant to augment each other).

${ }^{78}$ H.R. ReP. No. 109-31, supra note 14, at 129 ("The use of the term 'forward' in the definition of 'swap agreement' is not intended to refer only to transactions that fall within the definition of 'forward contract.' Instead, a 'forward' transaction could be a 'swap agreement' even if not a 'forward contract.'"').

${ }^{79}$ H.R. REP. NO. 109-31, supra note 14, at 131 explains:

The definition of 'financial participant' (as with the other provisions of the Code relating to 'securities contracts,' 'forward contracts,' 'commodity contracts,' 'repurchase agreements,' and 'swap agreements') is not mutually exclusive, i.e., an entity that qualifies as a 'financial participant' could also be a 'swap participant,' 'repo participant,' 'forward contract merchant,' 'commodity broker,' 'stockbroker,' 'securities clearing agency,' and/or 'financial institution.'
} 
The Code's protections may also capture "settlement payments" that are, in essence, preferential or fraudulent transfers to preexisting creditors and equityholders. This is most likely to occur in the context of financial transactions involving the debtor's own securities-stock, commercial paper, or other debt issued by the debtor. In transactions such as these, the counterparty is typically wearing two hats -it is, at the same time, party to a financial contract as well as one of the debtor's creditors or equityholders. This may occur when stockholders tender their shares in an LBO, when a debtor repurchases its stock via forward contracts, or when the debtor repurchases its commercial paper prior to maturity. In each case, the payments are simultaneously "settlement payments" to a counterparty and dividends to a shareholder (in the case of equity repurchases) or early repayments to a creditor (in the case of debt repurchases). This is potentially problematic when the settlement payments occur within the lookback periods for fraudulent conveyances ${ }^{80}$ and preferential transfers ${ }^{81} \mathrm{An}$ eve-of-bankruptcy settlement payment to a financial counterparty may be nothing more than an eve-of-bankruptcy dividend to a stockholder or preference to a creditor. Is there any room here for line-drawing by bankruptcy judges? We address this question in Section II.B.

\section{A. Financial Contracts versus Ordinary Loans}

An ordinary loan can be replicated by a combination of financial contracts. Simple economic theory - "put-call parity" - tells us as much. ${ }^{82}$ Consider, for example, a simple forward in which Party A agrees to purchase a security one year hence from Party B for $\$ 105$. The transaction enables Party A, at a price, to take on the risk (upside and down) associated with the price of the security. Now assume that, at the same time the parties execute the forward, they enter another contract: Party A sells the same or same type of security to Party B today at the current market price, say, $\$ 100$. The net result of these two transactions is a loan: A receives $\$ 100$ today (under the second contract), which it will repay with $\$ 5$

\footnotetext{
${ }^{80} \mathrm{Id}$. at $\S 1402$ (to be codified at 11 U.S.C. $\S 548(\mathrm{a})(1)$ ) (permitting avoidance of fraudulent transfers or obligations "made or incurred on or within 2 years before the date of the filing of the petition"); see also 11 U.S.C. $§ 544(b)(1)$ (permitting avoidance of certain transfers that are "voidable under applicable law," including non-bankruptcy fraudulent conveyance laws, which have varying statutes of limitations).

${ }^{81}$ BAPCPA $\S 1213(a)(1)$ (to be codified at 11 U.S.C. $\S 547(b)$ ) (permitting avoidance of preferential transfers that were made "on or within 90 days before the date of the filing of the petition" or "between ninety days and one year before the date of the filing of the petition, if such creditor at the time of such transfer was an insider").

82 See, e.g., Alvin C. Warren, Financial Contract Innovation and Income Tax Policy, 107 HARV. L. Rev. 460, 466 n.27 (1993).
} 
interest next year (under the first contract). Both contracts do indeed involve the sale of a security, but does this matter? No. In the first transaction, Party A takes on the risk of the underlying security; in the second, it disposes of that risk. Both transactions occur simultaneously, meaning that Party A never takes an economic interest in the security. All that remains is a loan from Party B to Party A, secured by temporary ownership of the security transferred to Party B. ${ }^{83}$

The first transaction (the forward) is undoubtedly a protected transaction under the Code. So is the second. Is the combination also protected, even if it is equivalent to an ordinary loan? It would certainly seem so, because the combination is essentially what market participants call a repurchase agreement or repo ${ }^{84}$ Some repos - those in which the underlying security is a T-Bill or other qualified security - have been explicitly protected by the Code since $1984 .{ }^{85}$ But what about other kinds of repos, such as those involving mortgage-backed securities or stock? Are they protected transactions (they are undoubtedly contracts "for the purchase, sale, or loan of a security" ${ }^{86}$ ) or are they unprotected secured loans? Prior to 2005, this was a hard question. At least one court, in Criimi Mae, ${ }^{87}$ was unwilling to conclude, without an evidentiary hearing, that the repo in question involved a transfer of ownership and hence a sale of securities. But the repo at issue in Criimi Mae, notwithstanding some non-standard

\footnotetext{
${ }^{83}$ Formally, there is of course a difference from a secured loan, as Party B becomes the owner of the security and is, in most cases, free to dispose of it. This is akin, but not identical, to a security interest in the security. See In re Criimi Mae, Inc., 251 B.R. 796, 801 (Bankr. D. Md. 2000) ("One essential difference in the rights of a transferee under a true sale, as opposed to the transferee of a lien, is the right of the transferee to dispose of the securities and otherwise to deal with the securities as the absolute property of the transferee during the pendency of the repurchase/repayment obligation under the contract").

${ }^{84}$ JOHN C. Hull, OptiOnS, Futures, AND OTHER Derivatives 94 (5th ed. 2003).

${ }^{85}$ See supra note 24 and accompanying text.

86 See 11 U.S.C. § 741(7)(A)(i) (2000). This is plain when the repo is decomposed into its constituent parts - a securities contract and a forward.

87251 B.R. at 805. Criimi Mae "sent shockwaves through the financial industry." Jeanne L. Schroeder, A Repo Opera: How Criimi Mae Got Repos Backwards, 76 Am BANKR. L.J. 565, 567 (2002). Other courts have respected the parties' decision to structure transactions as a repo instead of a secured loan. See In re Bevill, Bresler \& Schulman Asset Mgmt. Corp., 67 B.R. 557, 598 (Bankr. D. N.J. 1986) (noting "mere presence of secured loan characteristics in repo and reverse repo agreement" not enough to preclude decision to structure transactions as purchases and sales); see also Jeanne L. Schroeder, Repo Madness: The Characterization of Repurchase Agreements under the Bankruptcy Code and the U.C.C., 46 SYRACUSE L. REV. 999, 1010-17 (1996) (analyzing case law prior to Criimi Mae); Harold S. Novikoff, (Re)Characterization in Bankruptcy of Transactions Affecting the Public Markets: The Treatment of Repurchase Agreements and its Implications, SK092 ALI-ABA 237 (2004) [hereinafter Novikoff] (analyzing Criimi Mae and other case law regarding repos).
} 
provisions ${ }^{88}$ was economically equivalent to the "repurchase agreements" explicitly protected by the Code. If that repo had an uncertain status under the pre-2005 Code, what was the status of any other combination of financial contracts that is functionally equivalent to a loan? And if a court "must examine the substantive provisions of the contract," ${ }^{89}$ what conclusion would it reach? A repo-even one protected by the Code-is as much a loan as a financial contract. ${ }^{90}$

Some of these questions are explicitly addressed by the Reform Act. All repos, including those at issue in Criimi Mae, are now explicitly covered by the definition of "securities contract." 91 This amendment, the legislative history makes clear, is meant to "eliminate any inquiry under section 555 and related provisions as to whether a repurchase or reverse repurchase transaction is a purchase and sale transaction or a secured financing." ${ }^{92}$

But other combinations of financial contracts are not explicitly addressed by the Act. The possibilities are endless. A total return swap, combined with a securities purchase, achieves the same effect as a repo: it is economically equivalent to a loan. ${ }^{93}$ Or consider a variant on the "prepay" transactions at issue

\footnotetext{
88 See Novikoff, supra note 87, at 249 (noting Criimi Mae court was particularly impressed by "the (non-standard) requirement that the repo buyer sell back the identical securities to the repo seller").

${ }^{89}$ Criimi Mae, 251 B.R. at 802.

${ }^{90}$ See Granite Partners L.P. v. Bear, Sterns \& Co., 17 F.Supp.2d 275, 301 (S.D.N.Y. 1998), explaining that, in a repo,:
}

[t]he seller's interest in the market value of the securities is no greater in a secured loan transaction where he retains beneficial ownership of the securities than in a purchase and sale transaction where he is contractually bound to reacquire ownership of them. Clearly, any attempt to determine whether a repo or reverse repo transaction is more like a secured loan than a purchase and sale by weighing economic factors on a finely tuned balance scale would be an essentially formalistic and ultimately unproductive exercise.

See also Novikoff, supra note 87, at 242 (noting that repos and reverse repos are hybrid transactions, which appear, as an economic matter, similar to loans secured by repo securities).

${ }^{91}$ BAPCPA § 907(a)(2) (to be codified at 11 U.S.C. § 741(7)(A)(i)).

${ }_{92}$ H.R. REP NO. 109-31, supra note 14, at 130 (emphasis added).

${ }_{93}$ See, e.g., David Z. Nirenberg \& Steven L. Kopp, Credit Derivatives: Tax Treatment of Total Return Swaps, Default Swaps, and Credit-Linked Notes, 87 J. TAX'N 82, 83 (1997):

A total return swap sometimes is used to achieve off-balance-sheet financing of a reference security. In that event, the would-be borrower (the total return receiver) sells the reference security to a purchaser and at the same time enters into a total return swap with the purchaser (the total return payer) under which the would-be borrower receives the total return on that security. The two 
in Enron's bankruptcy. ${ }^{94}$ Party A agrees to pay $\$ 105$ for delivery of one unit of a commodity (say, oil) one year hence. Party A will pay when Party B delivers the commodity. Suppose, in addition, that the parties simultaneously enter a "prepaid" forward contract in which Party B agrees to pay $\$ 100$ today for delivery of one unit of the same commodity next year. This is a "prepaid" forward because Party B tenders payment today, not when the commodity is delivered. ${ }^{95}$ As in a repo, the net effect of these two transactions is a loan: Party A receives $\$ 100$ today, which will be repaid with interest next year (\$105). And, as in repos, Party A bears none of the economic risk surrounding the market price of the underlying commodity: it assumes the risk in one transaction and surrenders it in the other.

Does the Code offer a safe harbor for combinations such as these? Absent badges of fraud, it appears to do so. A combination of financial contracts, even one that mimics a loan, merits protection if the underlying contracts fall within formal categories explicitly protected by the Code. This follows directly from the text of the new Code. It protects not only any transaction that a market participant would call a "swap," "repo," "forward," "commodity contract," or "securities contract," ${ }^{96}$ but also any combination of such transactions. No

transactions taken together are economically equivalent to the seller retaining ownership of the reference security and borrowing what are nominally the proceeds of the sale of the security from the purchaser.

${ }^{94}$ See Second Interim Report of Neil Batson, Court-Appointed Examiner, Case No. 01-16034, at 58 (Jan. 21, 2003), available at http://www.enron.com/corp/por/pdfs/examiner2/InterimReport2ofExaminer.pdf (examining Enron's prepay transactions).

${ }^{95}$ This feature, in itself, is not unusual. Prepaid forward transactions are part and parcel of the forward markets. See, e.g., David M. Schizer, Balance in the Taxation of Derivative Securities: An Agenda for Reform, 104 CoLUM. L. REv. 1886, 1901-03 (2004) (identifying various common derivative transactions, including prepaid forwards).

${ }^{96}$ The Code defines none of these terms; judges must turn to the market and rely upon industry definitions. See supra note 36 and accompanying text. Indeed, this type of analysischaracterizing transactions based on industry custom - is explicitly advocated by the opening clause in the definition of "swap agreement." BAPCPA § 907(a)(1)(E) (to be codified at 11 U.S.C. § 101(53B)(ii)). Instead of simply protecting any "transaction that is similar to" others explicitly listed in other subsections, the clause protects a "similar" transaction if and only if it (I) "is of a type that has been, is presently, or in the future becomes the subject of recurrent dealings in the swap markets" and (II) "is a forward, swap, future, or option on one or more rates," or one of several other types of transactions. Id. Judges, then, are directed to characterize similar transactions based on (I) their commonality in the marketplace and (II) whether a market participant would call them a "forward, swap, future" or other listed transaction. 
exception is made for combinations that, in effect, resemble a loan. ${ }^{97}$ Additional support for this conclusion can be found in the new definition of "securities contract," in section 741(7). ${ }^{98}$ It extends protection to "any other agreement or transaction that is similar to" ${ }^{\prime \prime 9}$ those mentioned elsewhere in the definition, including "repurchase or reverse repurchase transactions." 100 Thus, a combination of agreements that resembles a repo would seem to merit protection, even if it exhibits loan-like features. ${ }^{101}$

The new Code, in other words, places form over substance in characterizing protected transactions. A combination of contracts merits protection-regardless of its underlying economics - if the contracts are commonly recognized in the marketplace as swaps, forwards, or another type of contract protected by the Code. Indeed, margin loans - loans secured by the debtor's securities portfolioare now explicitly protected even though they are, in form and in substance, simply loans. ${ }^{102}$ To boot, the Act significantly restricts the equitable powers of bankruptcy courts. Section 362(o) now emphasizes that a counterparty's setoff rights "shall not be stayed by any order of a court or administrative agency in any proceeding under this title." 103 Similar language was already part of sections $555,556,559$ and 560 prior to the Reform Act. ${ }^{104}$

This emphasis on form-over-substance is evident in the legislative history as well. Protection for repos was added in order to prevent "any inquiry" into

\footnotetext{
97 See BAPCPA § 907(a)(1)(A) (to be codified at 11 U.S.C. $\S 101(25)(B)$ ); id. at $\S 907(a)(1)(C)$ (to be codified at 11 U.S.C. $\S 101(47)(A)$ ); id. at $\S 907(a)(1)$ (E) (to be codified at 11 U.S.C. § 101(53B)(A)); $i d$. at $\S 907(\mathrm{a})(2)$ (to be codified at $\S 741(7)(\mathrm{A})$ ); id. at $\S 907(\mathrm{a})(3)$ (to be codified at $\S 761(4)$ ). Thus, a combination of prepaid and postpaid commodity forwards would seem to merit protection, because it is a combination of "commodity forwards" expressly included in the definition of swap agreements.

${ }_{98}$ BAPCPA $\S 907(a)(2)$ (to be codified at 11 U.S.C. $\S 741(7)$ ).

${ }^{99} I d$. (to be codified at 11 U.S.C. $\left.\S 741(7)(\mathrm{A})(\mathrm{v})\right)$.

$100 \mathrm{Id}$. (to be codified at 11 U.S.C. $\S 741(7)(\mathrm{A})(\mathrm{i})$ ).

101 We recognize that our analysis may raise some eyebrows. It might be argued that the Act protects combinations of contracts if, and only if, the combinations themselves (not just the component contracts) are recognized in the financial markets. Thus, repos merit protection, but the "prepay" structures used by Enron do not. This argument, however, finds no support in the Act or its legislative history.

102 BAPCPA $\S$ 907(a)(2) (to be codified at 11 U.S.C. $\S 741(7)(A)(i v)$ ).

${ }^{103} \mathrm{Id}$. at $\S 907(\mathrm{~d})(2)$ (to be codified at 11 U.S.C. $\S 362(\mathrm{o})$ ).

104 See, e.g., 11 U.S.C. $\$ 560$ (2000) (declaring swap participant's contractual right to liquidate, terminate, or accelerate agreement "shall not be stayed, avoided or otherwise limited by operation of any provision of this title or by order of a court or administrative agency in any proceeding under this title.").
} 
the economics of the transaction. ${ }^{105}$ If transactions in one legal category (loans) can be replicated by transactions in another (combinations of financial contracts), there is little courts can do to distinguish them. The virtue of the Reform Act is that it gets judges out of the business of trying to.

The legislative history, to be sure, contains multiple warnings that the Code's protections should not shelter ordinary commercial transactions. The new "definition of 'swap agreement,'" for example,

"should not be interpreted to permit parties to document non-swaps as swap transactions. Traditional commercial arrangements, such as supply agreements, or other non-financial market transactions, such as commercial, residential or consumer loans, cannot be treated as 'swaps' under ... the Bankruptcy Code simply because the parties purport to document or label the transactions as 'swap agreements."'106

Similarly, "the inclusion of 'margin loans' in the definition [of securities contract] is intended to encompass only those loans commonly known in the securities industry as 'margin loans,' .... 'Margin loans' do not include, however, other loans that happen to be secured by securities collateral." 107 These warnings, however, only underscore the importance of industry custom. A commercial loan that "the parties purport to document or label" as a "swap agreement" will not be recognized as a swap in the marketplace, especially if it involves an exchange of principal. ${ }^{108}$ Only transactions that are "commonly known" or "subject to recurrent dealings" in the relevant market merit protection.

Our discussion so far has assumed the absence of any badges of fraud. A transaction designed to defraud creditors should, of course, receive no safe harbor under the Code. If a combination of prepaid and postpaid forwards was used to manipulate financial reports (as allegedly it was in Enron ${ }^{109}$ ), it would be

${ }^{105}$ H.R. REP NO. 109-31, supra note 14, at 130.

${ }^{106} I d$. at 129 (emphasis supplied).

${ }^{107}$ Id. at 119 (emphasis supplied).

108 A hallmark of almost all swaps is the absence of an exchange of principal: the parties instead exchange cash flows calculated on the basis of a "notional" principal amount. See, e.g., Thrifty Oil Co. v. Bank of Am. Nat'l Trust and Savs. Ass'n, 322 F.3d 1039, 1042 (9th Cir. 2002) (explaining notional amount "provides the basis for calculating payment obligations but does not change hands."); see also Mount Lucas Assocs., Inc. v. MG Ref. \& Mktg., Inc., 682 N.Y.S.2d 14, 18 n.1 (N.Y. App. Div. 1998) (stating in most swaps, with exception of currency swaps, notional amount does not change hands and is not at risk); Feder, supra note 74, at 702 (explaining most swaps do not require exchange of principal).

109 Enron allegedly used the combination of prepaid and postpaid forwards to disguise loans and inflate earnings in an effort to deceive analysts and investors. See, e.g., SEC v. J.P. Morgan Chase, 
nonsensical if the transaction found a safe harbor under the Code. And it would be absurd if the trustee were unable to recover pre-petition transfers or prevent post-petition exercise of termination, liquidation, and setoff rights.

The Code does indeed avoid this absurdity. Settlement payments and other pre-petition transfers are recoverable under section 548(a)(1)(A) if they were made by the debtor "with actual intent to hinder, delay, or defraud" its creditors. ${ }^{110}$ But this provision may not go far enough. Nothing in the Code places an explicit limit on a counterparty's post-petition rights (termination, liquidation, and setoff) under a fraudulent transaction. One might be inferred from the court's equitable powers under section 105(a), ${ }^{111}$ but those powers are curtailed by new section $362(\mathrm{o})^{112}$ and other provisions that expressly prohibit "any order of a court" that would limit the exercise of these post-petition rights. 113

Instead of section 548(a)(1)(A), the primary ground for policing fraudulent transactions is, once again, industry custom. ${ }^{114}$ As several courts have noted, a transaction bearing badges of fraud will rarely be one that a market participant would call customary. ${ }^{115}$ This is because fraud must be concealed; otherwise it attracts investigation. In an effort to conceal fraud, parties will resort to unusual combinations of contracts and may rely upon "artificially" interposed parties,

SEC Litigation Release No. 18252 (July 28, 2003), available at

www.sec.gov/litigation/litreleases/lr18252.htm.

110 BAPCPA §907(e) (to be codified at 11 U.S.C. § 546(e), (f), (g)) (permitting avoidance under section 548(a)(1)(A)); id. at § 907(e) (to be codified at 11 U.S.C. § 546(j)) (permitting avoidance under section 548(a)(1)(A)).

11111 U.S.C. § 105(a) (2000) (permitting court to "issue any order, process, or judgment that is necessary or appropriate to carry out the provisions of this title.").

112 BAPCPA $\S 907(d)(2)$ (to be codified at 11 U.S.C. 362(o)).

113 See id. at $\S 907(j)$ (to be codified at 11 U.S.C. $§ 560$ ); see also supra note 92 and accompanying text.

${ }^{114}$ Non-bankruptcy law may be another important ground. The Code's protections extend, of course, only to enforceable transactions. A fraudulent transaction may be one that is void under state law. See, e.g., In re Enron Corp., 323 B.R. 857, 877-78 (Bankr. S.D.N.Y. 2005) (describing how pre-petition transfers to counterparty are not protected if transaction itself was void under relevant state law).

115 See, e.g., Kipperman v. Circle Trust (In re Grafton Partners), 321 B.R. 527, 540 (B.A.P. 9th Cir. 2005) (finding pre-petition transfers arising from fraudulent transactions not protected "settlement payments" because not "commonly used in the securities trade"); Jackson v. Mishkin (In re Adler, Coleman Clearing Corp.), 263 B.R. 406, 481 (S.D.N.Y. 2001) (concluding that fake purchases and short sales, designed to defraud debtor and its creditors, were so steeped in fraud that they "could not be considered as contemplating a normal 'completion of a securities transaction' as commonly understood in the securities industry"). 
both of which will render a financial transaction atypical, as the convoluted prepay transactions in Enron illustrate. ${ }^{116}$ Industry custom, then, is a benchmark for characterizing any financial transaction, even one bearing badges of fraud.

\section{B. Settlement Payments versus Voidable Transfers}

Industry custom may not go far enough. Custom is useful for identifying transactions that fit within a category of protected contracts, but it pays little attention to the identities of the counterparties or the nature of the securities underlying the contracts. A contract to purchase equity or debt securities can, undoubtedly, be a protected transaction. It might take the form of an openmarket repurchase of equity or commercial paper (falling into the definition of "securities contract") or a derivative transaction such as an equity forward (qualifying as a "swap agreement"). But what if the underlying securities were issued by the debtor and the repurchase occurred within ninety days (in the case of debt repurchases) or two years (in the case of equity repurchases) of its bankruptcy filing? ${ }^{117}$ Formally, the payments are simply "settlement payments" or "transfers" under a protected financial contract. In substance, however, the payments are pre-petition payments to equityholders or debtholders; a repurchase of equity may be little more than a dividend and a repurchase of commercial paper may just be a preferential transfer.

The tension here is between the Code's protections for financial contracts and its efforts to protect creditors' rights generally, as reflected in rules limiting preferential and fraudulent transfers. In some respects, this tension is precisely the point of the Code's financial contracts provisions: counterparties are given special treatment-treatment unavailable to general creditors and counterparties to executory contracts - because their claims raise distinct public policy concerns (nonpayment might contribute to systemic risk in the financial markets). ${ }^{118}$ But a different kind of tension arises when counterparties are not merely signatories to a financial transaction. When a counterparty is both signatory to a financial

\footnotetext{
116 In Enron's case, the "prepay transactions" were more complicated than the one illustrated above. Most importantly, to disguise the offsetting nature of its trades, Enron included third parties, effectively turning the two-party commodity forwards into circular three (or more) party arrangements. See In re Enron Corp., No. 01-16034 at 58-59 (Second Interim Report of Neil Batson, Court-Appointed Examiner 2003), available at www.enron.com/corp/por/pdfs/examiner2/InterimReport2ofExaminer.pdf (describing Enron prepay transactions as in "substance debt, funded by either large financial institutions or institutional investors").

117 See supra notes 80-81 and accompanying text.

${ }^{118}$ See supra notes 9-14 and accompanying text.
} 
contract and holder of debtor-issued securities on which the contract is written, the Code's financial-contract protections are doing double-duty. They are protecting settlement of a financial contract as well as payment of the claims or interests underlying that contract (that is, payment of debts to creditors or repurchase of stock from shareholders). The former protection is entirely consistent with the protection of financial contracts. The latter may be inconsistent with the protection of creditor's rights generally, particularly if it allows a preexisting creditor or equity holder to improve its position in bankruptcy merely by executing a pre-petition financial contract. ${ }^{119}$

If the counterparty acted "with actual intent to hinder, delay, or defraud" the debtor's other creditors, a judge can unwind any settlement payments. ${ }^{120}$ But evidence of such fraud is rare. There are many legitimate reasons for "issuerrelated" transactions involving the debtor's own securities. Consider, for example, an LBO, a common going-private transaction ${ }^{121}$ in which a company may use borrowed funds, typically secured debt, to repurchase its equity. ${ }^{122}$ The transaction may serve valid business purposes, but it can reorder priorities. At the end of the LBO, equityholders will have received payment and the firm taken

\footnotetext{
119 The "double-duty" problem can arise in other contexts as well. A claim for damages under an interest rate swap is ordinarily an allowed claim. But the swap may allow a creditor to recover amounts which, under a loan agreement, would potentially qualify as unmatured interest. Suppose Creditor extends a variable-rate loan to Debtor. At the same time, the parties enter an interest rate swap, effectively converting the variable rate loan into a fixed rate loan. If the debtor subsequently becomes insolvent and enters bankruptcy, Creditor will receive a claim for termination damages (if any) under the swap agreement. Had the parties instead entered into a fixed rate loan directly, similar termination damages would not have been allowed under 11 U.S.C. § 502(b)(2) (2000) to the extent they compensated Creditor for unmatured interest under the loan agreement. See, e.g., Thrifty Oil Co. v. Bank of Am. Nat'l Trust and Savs. Ass'n, 322 F.3d 1039, 1052 (9th Cir. 2002) (acknowledging the "speculative possibility that a lender could use interest rate swaps to evade Section 502(b)(2)," but concluding that "where the lender provides a standard interest rate swap to a sophisticated borrower and the swap serves a legitimate nonbankruptcy purpose, the lender's claim for termination damages is, for all purposes, indistinguishable from a claim filed by a non-lending swap dealer. Allowing the lender to collect termination damages in such a case offends none of the principles and policies of Section 502(b)(2).").

${ }^{120}$ BAPCPA § 1402(1)-(2) (to be codified at 11 U.S.C. § 548(a)(1)(A)).

${ }^{121} \mathrm{~A}$ leveraged buyout is a corporate takeover strategy, typically involving repurchase (via tender offer) of the firm's equity using borrowed funds. See RONALD J. GILSON \& BERNARD S. BLACK, THE LAW AND FinANCE Of CORPORATE ACQUisitions 399-401, 406-15 (2d ed. 1995); see also David Gray Carlson, Leveraged Buyouts in Bankruptcy, 20 GA. L. REv. 73, 74 (1985) (defining and further discussing LBO's). 122 See Carlson, supra note121, at 74 (explaining LBO may involve purchase of target corporation's assets or merger of target corporation with newly created entity).
} 
on significant secured debt, all to the disadvantage of unsecured creditors if the company finds itself in bankruptcy soon after. ${ }^{123}$ Or consider a stock buy-back program, which may be implemented when managers believe the debtor's stock is undervalued or when they hope (as Enron's management purportedly hoped) to hedge dilution of earnings resulting from employee stock option programs. ${ }^{124}$ Again priorities can be reordered: the buy-back transfers a firm's assets to its equityholders, to the disadvantage of creditors if the firm enters bankruptcy soon after. Yet another example is a debtor's decision to repurchase large amounts of its commercial paper prior to maturity and at a premium over the market price? ${ }^{125}$ The repurchase may occur on the eve of bankruptcy. But instead of seeking to favor certain creditors and defraud others, the firm may have repurchased the commercial paper simply to preserve its own credit rating. ${ }^{126}$

The reordering of priorities may be more troubling in some cases than others. It is perhaps most troubling when the counterparty to the financial contract was one of the debtor's creditors or equityholders prior to entering into the contract. This type of transaction is exemplified by Enron's early repurchase of outstanding commercial paper. ${ }^{127}$ In it, preexisting claimants may have gained

${ }^{123}$ Official Comm. Of Unsecured Creditors v. Fleet Retail Fin. Group (In re Hechinger Inv. Co. of Del.), 274 B.R. 71, 81 (Bankr. D. Del. 2002) ("[T]he former shareholders of the acquired company are replaced by secured creditors ... However, when the amount of debt incurred proves too much and the leveraged company collapses into bankruptcy, the downside risk caused by the increased debt to equity ratio is borne primarily by the unsecured creditors.").

${ }^{124}$ See Harrison J. Goldin, Court-Appointed Examiner in the Enron North America Corp. Bankruptcy Proceeding, Report Respecting his Investigation of the Role of Certain Entities in Transactions Pertaining to Special Purpose Entities, Nov. 14, 2003, p. 179 at n. 498 ("Like many companies, Enron utilized hedging of its [employee stock ownership program] to avoid potential dilution of its earnings."); see also In re Enron Corp., 323 B.R. 857 (Bankr. S.D.N.Y. 2005) (addressing the equity forward transactions executed by Enron in the context of hedging activities).

125 See In re Enron Corp., 325 B.R. 671, 685 (Bankr. S.D.N.Y. 2005) (describing repurchases by Enron of outstanding commercial paper prior to maturity, and noting that the price paid was allegedly much greater than the commercial paper's market value).

126 See e.g., In re Prima Co., 98 F.2d 952, 968 (7th Cir. 1938) (establishing soundness of repurchase and finding no fraud in repurchase even when "a few" of the notes outstanding are paid before they are due).

127 See In re Enron Corp., 325 B.R. 671 (Bankr. S.D.N.Y. 2005). There the court denied a motion to dismiss by J.P. Morgan and other defendants, to whom Enron had made prepetition transfers of over $\$ 1$ billion in prepayment of commercial paper. The defendants argued that these transfers were "settlement payments" protected by the Code's safe harbors. The court denied the defendant's motion, concluding that "because the $\S 546(\mathrm{e})$ safe harbor only protects from avoidance those settlement payments that are 'commonly used in the securities trade' and because, on a motion to dismiss, the Court must accept Enron's allegations as true, evidence must 
a safe exit from an ailing company by virtue of the safe harbors for financial contracts. Less troubling, perhaps, are cases where financial counterparties become claimants (most likely shareholders) at the time of or after entering the financial contract in an effort to hedge their exposure under the contract. This is often the case in stock buy-backs: the debtor may enter equity forward transactions with a financial institution, which hedges its exposure by immediately purchasing shares of the debtor's equity. ${ }^{128}$ These transactions are less troublesome because they don't function, at least as far as the counterparties to such derivatives are concerned, as a "safe exit" strategy for pre-existing creditors and shareholders. Counterparties become equityholders simply to hedge the risk underlying the contract itself. ${ }^{129}$

Do these transactions merit the same protection as financial contracts that achieve no similar reordering of priorities? Does the Code give judges room to distinguish transactions that function as a "safe exit" from those that reflect common hedging strategies? The answer to both questions, we believe, is no. The Code offers no cues that judges should vary its protections based on either the kind of underlying security (the debtor's own securities or something else) or the counterparty's parallel role as a claimant or equityholder of the debtor. To the contrary, the Reform Act remains silent on these oft-litigated issues. At the same time, the Act extends protection to the entire derivatives market and a broad range of securities contracts and repos. Nowhere are judges asked to distinguish transactions based on their subject matter. Protection is extended to any "margin payment" or "settlement payment" under a securities contract or repo and to any "transfer" under a derivative contract-with only one limitation, for cases involving intent to defraud creditors. ${ }^{130}$ Issuer-related transactions are singled

be presented as to whether payments made with respect to short-term commercial paper prior to the maturity date, at significantly above market prices and contrary to the offering documents in the midst of coercion by the holders of the commercial paper resulting from public announcements that make clear that the company is in a severe financial crisis constitute settlement payments commonly used in the securities trade." Id., at 685-86.

128 See, e.g., Enron Corp., 323 B.R. at 860 (explaining Bear Stearns, as counterparty, "purchased Enron stock from third parties to hedge its contractual obligation to Enron.").

${ }^{129}$ Transactions on the other extreme-in which counterparties do not hedge and thus never become claimants of the debtor - may also prove troublesome. One could imagine cases in which insiders, aware of the debtor's financial troubles, execute equity forwards with the debtor but do not hedge their exposure. This transaction would pay off handsomely if the debtor's share-price declined significantly, as it probably would in the vicinity of bankruptcy. A massive prebankruptcy looting by insiders would result. This case, however, would seem to fall clearly within the scope of section 548(a)(1)(A).

${ }^{130}$ See supra note 121. 
out elsewhere in the Code, but receive no attention here. ${ }^{131}$ As long as a prepetition payment fits within industry definitions of "settlement payment," "margin payment," or payment "under or in connection with a swap agreement," it is protected from avoidance. ${ }^{132}$

This conclusion finds support in the oft-repeated policy underlying the Code's safe harbors - reducing systemic risk in financial markets. That policy would be undermined by a rule that varied the Code's protections based on the subject matter of the transaction. Uncertainty would surround any settlement payment: a counterparty often deals with a broker and will be unaware whether it is party to an issuer-related transaction. ${ }^{133}$

Prior to the Reform Act, arguments along these lines persuaded appellate courts that LBO payments to shareholders are "settlement payments" under the pre-Reform Code. ${ }^{134}$ But some bankruptcy courts ${ }^{135}$ and commentators ${ }^{136}$

131 See e.g., 11 U.S.C. § 510(b) (2000) (subordinating rescission and damages claims arising from purchase or sale of debtor's own securities); THOMAS H. JACKSON, THE LOGIC AND LIMITS OF BANKRUPTCY LAW 63-64 (1986) (finding traditional rationale for subordination under section $510(b)$ is to prevent "the buyer of a risky security [(equity)] to bootstrap himself into a less risky class [(creditor)].").

${ }^{132}$ Reliance on industry definitions seems to shape the courts' approach in dealing with some of the dual hat problems discussed. See In re Enron Corp., 325 B.R. 671, 686 (Bankr. S.D.N.Y. 2005) (inquiring into common usage in securities industry of repurchases of commercial paper prior to maturity).

133 See Kaiser Steel Corp. v. Pearl Brewing Co. (In re Kaiser Steel Corp.), 952 F.2d 1230, 1241 (10th Cir. 1991) ("disruption in the securities industry - an inevitable result if leveraged buy outs can freely be unwound years after they occurred - is also a harm the statute was designed to avoid."). 134 See Lowenschuss v. Resorts Int'l., Inc. (In re Resorts Int'1., Inc.), 181 F.3d 505, 516 (3d Cir. 1999) (finding text of Code clear and concluding "[a] payment for shares during an LBO is obviously a common securities transaction, and we therefore hold that it is also a settlement payment for the purposes of section 546(e)."); Kaiser Steel, 952 F.2d at 1239-40 (reaching same conclusion and citing the "the legislative intent behind $\S 546$ to protect the nation's financial markets from the instability caused by the reversal of settled securities transactions").

135 See, e.g., Wieboldt Stores v. Schottenstein, 131 B.R. 655, 662-65 (Bankr. N.D. Ill. 1991) (holding LBO payments to shareholders were not "settlement payments," even if they were delivered through clearance and settlement system, because liquidity of market would not be affected by judicial order requiring shareholders to return payments); see also Jackson v. Mishkin (In re Adler, Coleman Clearing Corp.), 263 B.R. 406, 482 (S.D.N.Y. 2001) (finding "no evidence ... that any effects of reversing the Challenged Trades would spill over beyond [the debtor] into the securities industry to threaten the 'ripple effect' on other brokers and participants in the system that concerned Congress when it enacted 546(e)").

136 See, e.g., Gerald K. Smith \& Frank R. Kennedy, Fraudulent Transfers and Obligations: Issues of Current Interest, 43 S.C. L. REv. 709, 766 (1992) ("Neither the Bankruptcy Code provision nor a single industry publication which any of the parties has unearthed applies the word 'settlement' 
disagreed, reasoning that protection for LBO payments does little, if anything, to reduce systemic risk in financial markets. As one court put it, a rule avoiding these payments would "pose[] no significant threat to those in the clearance and settlement chain." ${ }^{137}$ Arguments of this sort rely exclusively on intuitions about public policy, not on the text of the Code. This is an important point even for non-textualists, because the policy underlying the Code is slippery. To what extent would stability in financial markets be affected by an amendment eliminating any or all of the protections for financial contracts? According to one view, not much. ${ }^{138}$ More importantly, there is little to commend a rule that varies the Code's protections based on (a court's assessment of) its importance to market stability. A rule like this is just as unpredictable as judicial inquiry into the "substance" of a transaction - an inquiry, we have seen, that the Code effectively rules out. ${ }^{139}$

\section{Conclusion}

The Reform Act makes many obvious changes to the Code, but its most important contributions may be its least apparent. It plainly expands the scope of protected transactions - swaps, forwards, commodity contracts, repos, and securities contracts - but it does so in a way that renders the concept of "protected parties" meaningless in the context of derivative contracts. The new definition of "swap" is so broad that a counterparty to almost any derivative contract-including any counterparty to a forward or commodity contract-will find a safe harbor under the Code.

The new definitions of protected transactions contain another significant but subtle change. These lengthy definitions-simple laundry lists of the names of popular transactions - cabin judicial discretion in an important way. Judges are discouraged from engaging in "substance over form" analysis. The new

to one-time mandatory redemptions or cash mergers where corporate assets are distributed to shareholders, rather than a market trade where shares and money are exchanged between buyers and sellers.") (internal citation omitted); see also Neil M. Garfinkel, No Way Out: Section 546(e) is no Escape for the Public Shareholder of a Failed LBO, 1991 COLUM. BUS. L. REV. 51, 66-67:

The inviolability of payments to shareholders is simply not basic to the operation of the clearance and settlement systems. Those systems will be only incidentally affected, if at all, if former shareholders are required to return payments they received in an LBO. Neither the system of guarantees nor the solvency of participants in the chain is threatened by a legal order in which payments to the shareholders by their brokers are subject to recovery by a trustee in bankruptcy.

137 Wieboldt Stores, 131 B.R. at 664.

${ }^{138}$ See Edwards \& Morrison, supra note 9, at 99-106.

139 See supra Part II.A. 
definitions are pure form; they protect transactions that fit within formal definitions developed in the marketplace. The role of the judge is to identify these industry definitions. If the contract fits the form, it's protected. This leads to some concerns about overbreadth, particularly with respect to certain transactions involving the debtor's own securities. Absent evidence of fraud, however, these concerns are not a problem, at least not a judge's problem.

Nothing in the language of the Act (or the rest of the Code) limits its breadth. Indeed the Act's breadth is its primary virtue: little uncertainty remains about the scope of the law or a judge's role in applying it. 